The Philosophical Journal of Conflict and Violence

Vol. III, Issue $1 / 2019$

(C) The Authors 2019

Available online at http://trivent-publishing.eu/

\title{
Fanaticism as a Worldview
}

\author{
Frank Chouraqui
}

Institute of Philosophy, Leiden University,

Netherlands, f.chouraqui@phil.leidenuniv.nl

\begin{abstract}
This article argues in favour of a formal definition of fanaticism as a certain relationship to one's beliefs that is informed by the assumption that there is a mutual incompatibility between consistency and moderation. It analyses this assumption as an expression of an implicit commitment to naïve realism. It then proposes a critique of such realism and finally it sketches an ontological alternative, able to philosophically and politically respond to and oppose fanaticism by showing the compossibility, on that ontological view, of moderation and consistency.
\end{abstract}

Keywords: Counter-radicalisation; Epistemology; Fanaticism; Fundamentalism; Nationalism; Non-Contradiction; Ontology; Violence.

DOI: 10.22618/TP.PJCV.20193.1.192002

The PJCV Journal is published by Trivent Publishing

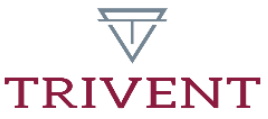

This is an Open Access article distributed in accordance with the Creative Commons Attribution Non Commercial (CCBY-NC-ND 4.0) license, which permits others to copy or share the article, provided original work is properly cited and that this is not done for commercial purposes. Users may not remix, transform, or build upon the material and may not distribute the modified material (bttp:/ / creativecommons.org/ licenses/by-nc/4.0/) 


\title{
Fanaticism as a Worldview
}

\author{
Frank Chouraqui \\ Institute of Philosophy, Leiden University, \\ Netherlands,f.chouraqui@phil.leidenuniv.nl
}

\begin{abstract}
This article argues in favour of a formal definition of fanaticism as a certain relationship to one's beliefs that is informed by the assumption that there is a mutual incompatibility between consistency and moderation. It analyses this assumption as an expression of an implicit commitment to naïve realism. It then proposes a critique of such realism and finally it sketches an ontological alternative, able to philosophically and politically respond to and oppose fanaticism by showing the compossibility, on that ontological view, of moderation and consistency.
\end{abstract}

Keywords: Counter-radicalisation; Epistemology; Fanaticism; Fundamentalism; Nationalism; Non-Contradiction; Ontology; Violence.

\section{Introduction}

This paper starts from two well-documented current socio-political problems. The first is the surprising resilience of radical modes of thinking in the face of widespread discourse promoting moderation, ${ }^{1}$ (despite some marginal successes of such endeavours). ${ }^{2}$ The second is the mutual reinforcement of opposite radical ideologies (for example radical Islam and white racism in Europe and North America), which multiplies their negative impact. ${ }^{3}$ However, fanaticism is not just a pragmatic problem to be dealt with by politicians and institutions, but it is also a philosophical problem. This suggests first that dealing with fanaticism involves philosophical work, and that conversely fanatical phenomena yield precious philosophical insights. These insights are in turn to be used for dealing effectively with fanaticism. This also suggests that in addition to moral and political grounds for fighting fanaticism, there exists philosophical grounds for it: fanaticism is not only wrong, it is also fallacious. Although this paper is obviously animated by political and moral concerns, the argument developed here is aimed at eradicating not a moral vice but a philosophical fallacy: the fallacy according to which moderation and consistency are in conflict.

In this paper, I focus on two insights and their consequences for the ideological struggle against fanaticism. First, fanaticism should be defined not in terms of its content but in terms of its form. Secondly, its political effectiveness, potency and resilience are dependent on a certain ontological position, which I characterize as naïve realism. As a consequence, any effective opposition to fanaticism will have to repudiate naïve realism and support itself with another kind of ontology. In order to address this problem, I argue that we must focus not

\footnotetext{
1 Anne Speckhard, Talking to Terrorists (McLean, VA: Advances Press, 2012); Christopher Boucek, "Losing in the Battlefield of the Mind," International Herald Tribune (04/12/2008).

2 Rohan Gunaratna \& Mohamed Bin Ali (eds). Terrorist Rehabilitation, a New frontier in Counter-Terrorism (London: Imperial College Press, 2015).

${ }^{3}$ John D. Hathcoat \& Laura Barnes, "Explaining the relationship among fundamentalism and authoritarianism: An epistemic connection," The International Journal for the Psychology of Religion 20/2 (2010): 73-84.
} 
only on the ideological content of radical views but also on the specific kind of relations that their adherents entertain with their own beliefs. In this light, I aim to show that such modes of adhesion privilege the value of consistency over the value of moderation. I further argue that the mainstream and so-called fanatics share the same assumption according to which consistency and moderation are bound to conflict, leading counter-radicalisation discourse to either turn into opposite radicalisms, or to undermine themselves. I then argue that this alternative is not inevitable, but rather that it relies on a faulty (although dominant) ontology.

I then seek to establish an alternative ontology able to provide a positive ground to moderation, at the same time as to account for its compatibility with the imperative of consistency. I argue that the deficit that afflicts moderation arises from the cognitivist premise according to which objective reality precedes belief and that conversely, belief is aimed at reality so construed. ${ }^{4}$ An alternative account of belief takes our engagement with fictional representations as its paradigm for the engagement with fiction circumvents the cognitive assumption. I then examine the consequences that such a constructivist account of belief would have for the epistemic status of moderation.

I conclude the paper by suggesting that the requisite alternative ontology is to be sought in a combination of phenomenology, pragmatism and Nietzschean genealogy. The paper is divided into three parts: in the first part, I discuss the best way to characterize fanaticism; in the second, I discuss the ontological foundations of fanatic thinking as well as the foundations of its political expedience. In the third section, I outline an alternative ontology able to support a counter-push both politically and philosophically.

\section{Characterizing Fanaticism}

\section{A. Common Definitions}

Although there is little consensus about a technical definition of fanaticism which would distinguish it from its cognates (including extremism, radicalism, fundamentalism etc.) or arbitrate the relations between them, one could draw both from the literature, the history of the concept and from common usage, that fanaticism is usually conceived along one or both of the two following lines: The content view of fanaticism argues that fanaticism is the holding of extreme views; the epistemic view contends that fanaticism is an intellectual flaw; broadly speaking, the inability to take into account facts that do not square with our own worldview: closemindedness. ${ }^{5}$ There are problems with both views, and I argue, these problems have practical consequences: they run the risk of locking us into counter-productive tactics to counter fanaticism, indeed, the very ones that we, as a civilization, are caught in at present.

The content view runs into one major problem. It has to do with the fact that extreme views cannot account for the negative valence of the notion of fanaticism. This is first because some extreme views are reasonable. Take the case of the eco-warrior who knows that overpopulation will cause the demise of the entire human race and is therefore wiling to murderously eliminate a huge chunk of the population. Although this is a strategy open to objections, there is nothing a priori unreasonable about it. ${ }^{6}$ The second has to do with the fact that extremism is reversible: the moderate is as far removed from the extremist as the extremist from the

\footnotetext{
4 Asbjorn Steglich-Petersen, “The No-Guidance Argument,” Theoria 79 (2013): 279-283.

${ }^{5}$ Alberto Toscano, Fanaticism (New York: Verso, 2016).

${ }^{6}$ In the 2014 movie Kingsman, the Secret Service (directed by Matthew Vaughn) the main antagonist is Richmond Valentine, a philanthropist eco-warrior bent on forcefully enacting the necessary population reduction through terroristic means. The tension at the heart of the plot revolves around the impossibility to dismiss Valentine's logic.
} 
moderate, and so both positions appear extreme to each other. This suggests that the content view simply amounts to reducing fanaticism to an epithet for the extreme views we disagree with. Any debate premised on the content view will be haunted by the spectre of relativism, and any effort to counter fanaticism will thereby lose any bite.

The epistemic view runs into one major problem too. In short, the fact that close-mindedness is a universally shared trait and one that is largely beneficial. ${ }^{7}$ Any theory of fanaticism that invests too much on the notion of close-mindedness will become either unable to account for what makes fanaticism special (including what makes it especially wrong) or unable to talk of any non-fanatic attitude. It shall be reduced to distinguishing fanaticism and nonfanaticism in terms of degrees. This is ruinous, both philosophically and politically, for degrees are comparative. This would return us to the symmetry claim ${ }^{8}$ and the problem of relativism according to which there is no non-fanatic ground from which fanaticism can be opposed justifiably. Yet, in our everyday sense, we do believe that some people are not fanatics (although close-minded in the relevant sense) while some others are.

In addition, both views run into an insufficiency. They do not seem to do justice to the fact that different fanaticisms do not coexist comfortably with each other, rather they tend to compete with each other. The rivalry between different fanatical views seems to be at the core of fanatical phenomena at least in so far as they are involved with violence. ${ }^{9}$ Neither the content view nor the close-mindedness view does justice to this fact at the appropriate level (they probably can accommodate it pragmatically, but without making it structural). As I shall suggest below, this requires at least the introduction into the definition of a formal factor of generalisation to account for the fact that fanaticism has some totalizing tendencies that transform the difference between fanatical worldviews into rivalries.

\section{B. Some Empirical Hints}

If any progress towards a usable concept of fanaticism is to be made, we must return to its salient features as they are related to what this concept should be used for (namely for articulating the intuition that something is wrong with it). I shall focus on three structural characteristics of fanatical phenomena and argue that a usable definition of the concept should directly account for all three.

The first is that "de-radicalization" and "counter-radicalisation" efforts have generally poor results. This is now widely acknowledged by specialists. ${ }^{10}$ An interesting fact about such failure is that they are verified across different kinds of fanaticisms (including religious cults, white supremacy, mass populism, Islamic fundamentalism, and guerrilla violence): they do not depend on the contents that such efforts are aimed at questioning. Many explanations for such poor results have been proposed, and there is no reason to think that they are mutually exclusive. These include administrative mismanagement (including blatant blunders), the counter-effects whereby any resistance to fanatical ideologies reinforces the siege mentalities of the subjects, and the failure at changing the subject's attitude (in some cases, with subjects exchanging a radical worldview for another).

\footnotetext{
${ }^{7}$ Arie Kruglanski, Lay Epistemics and Human Knowledge (New York: Plenum Press, 1989); Arie Kruglanski, The Psychology of Closed-Mindedness (New York and Hove: Psychology Press, 2004); Jeremy Fantl, "A Defense of Dogmatism." Oxford Studies in Epistemology 4. (2013): 34-57.

8 Glen Newey, Virtue, Reason and Toleration (Edinburgh: Edinburgh University Press, 1999).

${ }_{9}^{9}$ Bertrand Russell, Power: A New Social Analysis (London, Routledge 1938/2004), 98.

10 Anne Speckhard, Talking to Terrorists (McLean, VA: Advances Press, 2012); Christopher Boucek, "Losing in the Battlefield of the Mind," International Herald Tribune (04/12/2008).
} 
The second is the widespread (though controversial) view in critical theory, ideology critiques and their surrounding fields that the expansion of Western enlightenment has not coincided with the decrease of fanaticism. Again, it seems to conflict with the content view insofar as the spread of what could only, on this view, be considered to be non-fanatical contents has not reduced fanaticism. Returning to the case of the eco-warrior, it seems that there are fanatic ways to embrace good contents.

The third empirical remark has been outlined above already: fanaticisms do not coexist well, rather they seem to all be on a common collision course with each other. It may be seen now that this fact interacts in interesting ways with the objection to the epistemic vice account of fanaticism ${ }^{11}$ : although defining fanaticism as close-mindedness is untenable, we must retain from that account its emphasis on the exclusionary view of fanaticism: fanaticism is not closemindedness, but, like close-mindedness, it is exclusionary. Below, I suggest that the exclusionary character can be accounted for without commitment to close-mindedness if one embraces the formal view.

\section{The Formal Definition}

From the failure of the intuitive definitions of fanaticism as content and fanaticism as epistemic vice, we learn that fanaticism should be defined by its form, and that it must include an exclusionary factor distinct from close-mindedness. The empirical remarks briefly outlined above also point to the necessity to take a view according to which fanaticism is independent from its contents and yet not reducible to universal neurobiological factors. I suggest that these requirements can be addressed by a formal definition of fanaticism such as the following: Fanaticism is the worldview that results from the assumption that consistency cannot accommodate moderation. As a result, fanaticism is not characterised by its content but by its form, it is a certain relation to one's own beliefs dominated by a concern for consistency, both intellectual and ethical: a fanatic regards moderation as an anomaly. In this view, moderation is either the inability to act on one's beliefs (this is frequently denounced as hypocrisy or akrasia ${ }^{12}$ or the inability to bring distinct beliefs into agreement). Importantly, and against a dominant prejudice, fanaticism is therefore to be regarded as connected to rationalism. ${ }^{13}$ I see three bundles of advantages to such a view:

Firstly, it aptly deals with the requirements outlined above: it has room for a great diversity of fanatical contents (for example how opposite views can be both fanatical, and indeed, how any view at all can be fanatically embraced). It also accommodates for the rivalry and the mutual reinforcement between different fanaticisms: namely, the fact that in fanaticism, difference counts as opposition; and therefore, that different views count as an opportunity to fulfil one's existential commitment to act in accordance to one's beliefs, which is the mechanism that supports mutual reinforcement. In addition, it accounts for the failure of contentbased counter-radicalisation procedures as well as a host of more contingent problems: how fanatics change ideological contents more easily than they change from fanaticism to moderation etc. All of which suggest that fanaticism is infra-doxastic: it precedes and informs beliefcontents, rather than result from them. A further advantage of the formal definition is that it allows us to systematise all these widely acknowledged aspects of fanaticism under the commitment to one principle, namely, the principle of consistency (in so-doing, it also satisfies a

\footnotetext{
${ }^{11}$ Quassim Cassam. "Vice Epistemology," The Monist 99/2 (2016):159-180.

12 Sarah Stroud \& Christine Tappolet (eds.), Weakness of Will and Practical Irrationality (Oxford: Clarendon Press, 2003).

${ }^{13}$ We find a similar argument about intolerance in Glen Newey, "Political Toleration: A Reply to Jones," British Journal of Political Science 41/1 (2011): 223-227.
} 
widespread intuition of critical theory: that rationalism, which is inseparable form a commitment to consistency is not the opposite of fanaticism).

Indeed, it is this commitment to consistency that is formal enough to accommodate any content, and at the same time contains an element of competition to which fanatic totalitarianism and therefore fanatic violence can be traced. Consistency, argues Dworkin, is naturally a totalising concept (he even directly connects "coherency" with "competition"14 although the view is diagnosed and criticized by Williams ${ }^{15}$, as it had been criticised by William James). ${ }^{16}$ When one adopts the principle of consistency, one always already makes a claim about everything: namely, that any new phenomenon stands either as a corroboration of the pre-existing theory, or as a refutation of it. In a consistent world, non datur saltus, and so coexistence is only guaranteed by consistency. In short, fanaticism, like rationalism (of which it is a chief species) is committed to what one might call a plane of universal competition, where difference is cashed out as conflict.

Secondly, and more philosophically, we can see how this notion of fanaticism, which connects it to rationalism, accounts for the poor-child place of moderation in rationalist ideologies (such as Western democratic ideologies). If we normatively praise moderation at every turn, we are hard-pressed to justify it except by appealing to other anomalies such as compromise, cowardice, hypocrisy, vagueness, superficiality, relativism, scepticism or laziness. It is for this reason for example, that William James famously defines fanaticism in terms of a virtue: it is "loyalty taken to the extreme."17

Thirdly, as pointed above, this construal of fanaticism allows us to account for the widely noted connection between fanaticism and violence. ${ }^{18}$ As such, it leads to a better understanding of fanatic violence. In particular, it pays close attention to the fact that the fanatical recourse to violence is characterized by its internality: it is demanded that any call to avoiding violence be justified in terms of the fanatics' ideology itself. Any external appeal to non-violence appearing immediately as compromise or any of the anomalies listed above. We need a good reason to avoid violence, and only the very fanatical system we are trying to curtail can produce such a reason. The onus is on non-violence to justify itself in terms consistent with the fanatic's view and this reason must be consistent with the set of beliefs that motivated the violence in the first place. In short, the formal account pays attention to the fact that in any rational system, whether it be a so-called fanatical one or our "open" societies, consistency is valued more highly than non-violence.

\section{The Ontological Foundations of Fanaticism}

Seen through this lens, fanaticism is to be understood as a challenge to mainstream normative views insofar as it exploits the fact that such views rely on the tension between our epistemic valuation of consistency and our normative valuation of moderation. It drives a wedge between these two virtues that we would wish to be able to value at the same time and forces

\footnotetext{
${ }^{14}$ Ronald Dworkin, Justice for Hedgehogs (Cambridge, MA.: Harvard University Press. 2011), 108.

15 Bernard Williams, "Ethical Consistency," in Problems of the Self (Cambridge: Cambridge University Press, 1965/1973), 166-186; Bernard Williams, Ethics and the Limits of Philosophy. (Cambridge, MA.: Harvard University Press, 1985).

${ }^{16}$ William James, The Varieties of Religious Experience: A Study in Human Nature (Oxford: Oxford University Press, 2012).

${ }^{17} \mathrm{Ibid}$.

${ }^{18}$ Georg Wilhelm Friedrich Hegel, Grundlinien der Philosophie des Rechts (Leipzig: Reclam, 2013), Preface, Section 5 .
} 
us to choose. Firstly therefore, fanaticism places toleration before its contradictions. ${ }^{19}$ Secondly, it places our claim to live and our claim to think in contradiction: in the current epistemological paradigm, fanaticism is "inevitable" because we are committed to consistency, and moderation is "inevitable" because we are committed to life (as transgression, compromise, state of exception etc.). As a result: fanaticism has an existential deficit: it makes life difficult. Moderation on the other hand, has a theoretical deficit: it has no sound logical basis. In short, fanaticism is unliveable, and this should provide the justification for any challenge to fanaticism (as mentioned above, the symmetry thesis prevents any other ground for objecting to fanaticism). As I mentioned at the outset, the argument developed here is aimed at eradicating not a moral vice but a philosophical fallacy: if we are to overcome fanaticism, it will have to be by uncovering a fallacy at the very heart of its commitment to consistency.

The fact that moderation and fanaticism each satisfy one imperative and fail another is not to suggest a parallelism between them however. These two inevitable tendencies compete with each other and dominate each other according to whether the situation emphasises existential or theoretical concerns. Here, a structural advantage of fanaticism comes to the fore: as we painfully witness in the current context, times of pressure and high stakes play to the strengths of fanaticism, whereas moderation is at its best in times of lesser pressure. In short, moderation dominates when it is less necessary, and fanaticism dominates when moderation is most necessary. This is mostly because times of pressure call for concerted solutions, that is, they appeal to consciousness, and therefore rely on theoretical soundness, whereas times of "business as usual" only requires inertia and the prolonging of the status quo; they go without saying or without thinking. Present-day "open" societies are experiencing a back-andforth between possible but unnecessary moderation (when things go well) and necessary but impossible moderation (in times of crisis). Fanaticism and discourse have a structural affinity, which lies in their common commitment to consistency. In the appeal to concerted decisions, discourses become instrumental, and this is further magnified in times of globalised media where existential threats are not only discussed but even made real to the public through discursive reports. The advantage of fanaticism therefore is its ability to dominate discourse in a time where discourse dominates policy, public opinion, and the lives of societies and of individuals.

So, it seems that fanaticism applies pressure on the most vulnerable point of a long tradition of practical philosophy: the assumption that the normative and the epistemic can be made consistent, that one need not choose between truth and goodness. The situation is dire: we, so-called enlightened liberals, are de facto committed to the fanaticism we reject, and our worldview is constantly torn apart by the tension between moderation and consistency.

Such a nihilistic conclusion cannot be dismissed offhand, and there is obviously no fact that could refute it. However, its validity depends on the failure of alternative views. The only possible way to test it is therefore to examine whether such an alternative, one in which moderation remains valuable, fanaticism remains blameworthy, and truth remains able to support such judgments, is indeed open. Here is room for hope: as I have presented it so far, the quandary is inherited from a specific ontological context, one that need not be taken for granted. Indeed, it is one that has been discarded as naïve realism in many other quarters of philosophy, although ethicists and political philosophers seem to have clung to it with more resolve than their more theoretically-minded colleagues. In the rest of this paper, I examine under what conditions an alternative to naïve realism is viable and able to conform to our intuitions that fanaticism is both wrong and mistaken without having to give up the principle of consistency.

\footnotetext{
${ }^{19}$ Glen Newey, "Political Toleration: A Reply to Jones," British Journal of Political Science 41/1 (2011): 223-227.
} 


\section{Alternative Ontology}

Let us start by looking at the structure of this faulty paradigm: such naive realism is based on the idea that reality precedes belief (or, in more contemporary language, that belief aims at reality, assumed to precede it). ${ }^{20}$ It contends that:

(a) Beliefs are the recognition of (alleged) reality. In other words, beliefs are the result of some sort of apprehension (direct or indirect) of a state of affairs that is independent from them, and which precedes them.

(b) This reality is univocal. Beliefs are reducible to statements about existence, where a true belief has a real truth-maker, which is located in the state of affairs, and false beliefs do not (note that this view is agnostic about negative truth-makers). In short, the mutual opposition of truth and falsity is taken to correspond with the opposition of existence and non-existence.

(c) This reality is one: all existing things (all possible objects of true beliefs) are compossible, and taken together, they amount to the whole of reality.

(d) This is why a fanatic's ideology has a universal and exclusive vocation, or as I suggested above, fanaticism is committed to a "unique plan of universal competition": it is taken to be "true" in the sense of "having an exclusionary relationship to other beliefs": either they are consistent with it (and therefore the one is contained in the other), or they are not and one of the two is wrong. In short, difference is reduced to identity or to falsehood, and pluralism is therefore untenable and reduced to either relativism or scepticism.

The good news is that (a) and (b) (and therefore (d)) can be challenged as being committed to naive realism by simply denying the precedence of reality over belief: this is what I shall here call the constructivist view. Although there is plethora of critiques of naive realism, it seems that when defined in the way I suggested above, the most potent angles of attack can be found in particular in three traditions: the first is post-Husserlian phenomenology and its contention that any independent and objective reality is a contradiction. On the contrary, phenomenology sees the notion of reality as derived from a basic engagement with the world, characterised as belief or "faith." 21 Note that this does not suggest that either the world or the subject of such engagement precedes this engagement. For a phenomenologist, this engagement is primary and gives rise to the notions of subject and object that later become crystallised in the ways they are portrayed by naive realism. What is naïve about naïve realism therefore, is its genealogical ignorance: it takes the result to be the source. For a phenomenologist like Merleau-Ponty for example, the world and the subject arise form an "unmotivated upsurge" which is a more fundamental reality. ${ }^{22}$ As a consequence, in this version of phenomenology, objects are "horizonal" insofar as they are never fully determined and independent. Rather, they only exist as a moment of this upsurge, and therefore, as moments, they always lead into the next moment, without acquiring enough determinacy to detach themselves from the flow of constitution.

The second tradition which one could appeal to is pragmatism and its contention that "reality" should be cashed out in terms of investment: reality is what counts as reality. ${ }^{23}$ Naïve realism, in this lens, is naïve because it abstractly detaches an experience of reality that could

\footnotetext{
${ }^{20}$ David Velleman, "On the aim of belief," in The Possibility of Practical Reason (Oxford: Oxford University Press, 2000).

${ }^{21}$ Maurice Merleau-Ponty, Le Visible et l'Invisible (Paris: Gallimard, 1961).

22 Maurice Merleau-Ponty, Phénoménologie de la Perception (Paris: Gallimard, 1945), xiv.

23 See William James, The Varieties of Religious Experience: A Study in Human Nature; Alfred Schutz, "On Multiple Realities," Philosophy and Phenomenological Research 5/4 (1945): 533-576.
} 
be entirely accounted for in terms of "counting as" from its dependence on interest. ${ }^{24}$ Correlatedly therefore, the third tradition that is best fit to serve as a starting point towards an alternative ontology is to be found in Nietzschean genealogical methods. For Nietzsche like for phenomenology, "the thing in itself is a contradiction" 25 and this is so because of a genealogical argument: a thing is what we call a thing, and there is no need to assume any kind of independent and primary reality in order to account for all "things." On the contrary, Nietzsche, just like pragmatist philosophers, regards interest (he says "will to power") as the source of the experience of things and of the notions of truth and of reality. ${ }^{26}$

Any alternative to naive realism as sketched out above will therefore have to commit to genealogy as a critical assessment of the primacy of reality, to phenomenology as a philosophy that places the impossibility of the thing-in-itself as its starting point and to interest as an unmotivated constitutive force. In so doing, it will commit to another three basic ontological structures: incrementalism and indeterminacy on the one hand, dynamism on the other and consequently, modalism.

Incrementalism and indeterminacy are two sides of the same coin. On this constructivist view, all objects, including reality as a whole, are derived from a process of constitution. As a result, their existence includes their perspectival character: to be is to be in a perspectival way. Yet, any perspective is partial, and any confluence of perspective is infinite, be it only because it involves the combination of present and recollected perspectives. ${ }^{27}$ This suggests that any object of thought or of perception is indeterminate (insofar as any determinacy would make it independent from constitution), and incremental in the sense that the process of constitution does not end in full determinacy, although it does involves the constant gathering of an ever richer bundle of perspectives.

The requirement of dynamism results from this: constitution becomes the heart of reality, and it is a process made infinite by the principle of indeterminacy that is the fundamental structure of being. As Aristotle points out, dynamicism has an unusual relation to the principle of contradiction, but not one that violates it. Rather, what it violates is the ontology of univocity. But, when said ontology is taken for granted, Aristotle complains, it is dynamicism that is given a bad name as contradictory: Heraclitean dynamicism, he writes, appears as a violation of the law of non-contradiction. ${ }^{28}$

Thirdly, constructivism is committed to modal ontology: the resulting ontology no longer undergirds any mutual exclusion between being and nothingness. Rather, to exist must be cashed out in terms of "existing as" where what objects exist "as" is potentially infinite (standard candidates include events, memories, fantasies, beliefs, metaphors etc.). By detaching itself from the univocity of naïve realism therefore, this alternative view also opens up the possibility of a consistent pluralism: objects that cannot coexist in a univocal world can very well coexist in an equivocal one. Indeed, this is contained in Aristotle's canonical formulation of our attachment to the law of non-contradiction (said attachment, remember, being the common ground between ourselves and the fanatics): "Evidently then, Aristotle declares, such a

\footnotetext{
${ }^{24}$ William James, The Varieties of Religious Experience: A Study in Human Nature, Ludwig Wittgenstein, Über Gewissheit (Frankfurt: Suhrkamp, 1984).

${ }^{25}$ Friedrich Nietzsche, Jenseits von Gut und Böse, 1886, in Nietzsche-Ausgabe, Abteilung VI, Band 2 (Berlin and New York: De Gruyter).

${ }^{26}$ Peter Poellner, Nietzsche and Metaphysics (Oxford and New York: Oxford University Press, 1995).

${ }^{27}$ Maurice Merleau-Ponty, Phénoménologie de la Perception (Paris: Gallimard, 1945), 30 ff.

28 Aristotle, Metaphysics, in The Complete Works of Aristotle, ed. Jonathan Barnes (Cambridge: Cambridge University Press, 1984), G, 3, 1005b, 19-20.
} 
principle is the most certain of all [...] that the same attribute cannot at the same time belong and not belong to the same subject in the same respect." 29

So, the resulting view opposes the naïve realist view: it argues:

(a) Not that "beliefs are derived from and aimed at (alleged) reality," but rather that beliefs and reality are contemporaneous, two moments of one single "unmotivated upsurge of the world."

(b) Not that this reality is univocal, but that reality is modal and incremental: to be real is always to be cashed out as "to be in a certain way and to not be in some other way."

(c) This reality is one. Here, the ontological premise that undergirds the value of the principle of non-contradiction remains valid.

(d) Thus, the conclusion drawn by naïve realism to the effect that therefore any ideology has a universal and exclusive vocation no longer follows, but rather ideologies are best defined as meaning-making, not meaning-retrieving systems, and therefore they can accommodate pluralism and consistency. This is because the justification for a certain mode of meaning-making can no longer be traced to a being/non-being alternative and therefore to a truth/falsity alternative. As a result, we witness a multiplication of the grounds for the coexistence of (hitherto) conflicting beliefs on incremental and modal terms.

Concrete examples are easily forthcoming: conflicting statements have coexisted peacefully in a large number of areas of human activities in which univocity is challenged. In particular, one may think of the domains of fiction, play, myth and in general, metaphors or allegories. In all such cases, competing worlds avoid entering into conflict because they are not reduced to any unique plane of universal competition. On the contrary, their modal distinction preserves them, and preserves their compossibility. In spite of the anxieties expressed by an entire Platonic tradition, fiction (for example) does not threaten our sense of reality (or rather, it does so only for those who refuse to see the mode of fictionality as a relevant feature of fictional discourses-i.e., those who, like Plato, reduce fictions to lies). In short, being engrossed in a fiction does not mean having to choose against reality. This is confirmed by philological ${ }^{30}$ and anthropological evidence. ${ }^{31}$ Players, similarly, have always been familiar with the experience of the discrepancy between the intensity of their involvement in the game and their recognition that the game is, from another perspective, "only a game" namely: that its value does not transcend modality. Johan Huizinga explicitly justifies his revival of Schiller's idea that "man is only fully a human being when he plays" in his Homo Ludens, in terms of the emergency represented by Nazism, a fanaticism that ignores modalities. ${ }^{32}$ This strategy, although it has remained inarticulate, has featured among many of the great attempts to liberalise dogmas over the centuries: it returns to the disputes between literalists and allegoricists, with the latter simply claiming that two apparently competing views (say, creationism and Darwinism) can be made to coexist if and when one of the two is modified, i.e.: read as true in another (allegorical) mode.

This is not, one may note, an appeal to relativism: modalisations are not a free-for-all, they must be justified and of course, some ideological claims are often doubled with a meta-claim stating that at least some modalisations are forbidden; for example, one is forbidden from understanding such and such a rule as metaphorical, or for that matter, as literal. This is, by the way, both an advantage and a limit of my proposal. It is an advantage insofar as relativism

\footnotetext{
${ }^{29}$ Ibid., G, 3, 1005b, 19-20. Emphasis added.

30 Paul Veyne, Les Grecs ont-ils cru à leurs mythes? Essai sur l'imagination constituante (Paris: Seuil, 1983).

31 Octave Mannoni, "Je sais bien mais quand-même," in Clefs pour l'imaginaire. (Paris: Seuil, 1969).

32 Johan Huizinga, Homo Ludens. (London: Routledge, 1944).
} 
is a non-starter for any of the views or agents that we seek to address in the case of fanaticism. It is a limitation insofar as, although it does multiply the opportunities for compatibility, thereby reducing chances of conflict, it does not make such opportunities for coexistence infinite: conflict remains possible. But one must be clear as to the remaining conditions for such conflict: they are greatly reduced. First, one must have an explicit set of beliefs, which is in conflict with another explicit set of beliefs, in addition to an explicit set of beliefs about the proper and improper modalisations to be applied to each. In addition, one must bear in mind that the ontology sketched here regards all objects as hermeneutic objects: all objects are meaning-units, and as such, they contain a reducible but ineradicable indeterminacy which makes such univocal decisions always questionable.

Fanaticism, it seems, can be defeated only at the ontological level, and with its defeat, a tenable notion of moderation as pluralism becomes firmer: a commitment to an ontology that could stand as a plausible alternative to naive realism is therefore made urgent by the tension we find between our deeply held intuitions: that consistency is valuable and that so is moderation.

\section{References}

Aristotle. Metaphysics. In The Complete Works of Aristotle, Ed. Jonathan Barnes. Cambridge: Cambridge University Press, 1984.

Boucek, Christopher. "Losing in the Battlefield of the Mind." International Herald Tribune (04/12/2008).

Cassam, Quassim. "Vice Epistemology." The Monist 99/2 (2016): 159-180.

Dworkin, Ronald. Justice for Hedgehogs. Cambridge, MA.: Harvard University Press, 2011.

Fantl, Jeremy. "A Defense of Dogmatism.” Oxford Studies in Epistemology 4 (2003): 34-57.

Gunaratna, Rohan \& Bin Ali, Mohamed (eds). Terrorist Rehabilitation, a New frontier in CounterTerrorism. London: Imperial College Press, 2015.

Hathcoat, John D. \& Barnes, Laura. "Explaining the relationship among fundamentalism and authoritarianism: An epistemic connection." The International Journal for the Psychology of Religion 20/2 (2010): 73-84.

Hegel, Georg Wilhelm Friedrich. Grundlinien der Philosophie des Rechts. Leipzig: Reclam, 2013.

Huizinga, Johan. Homo Ludens. London: Routledge, 1944.

James, William. The Varieties of Religious Experience: A Study in Human Nature. Oxford: Oxford University Press, 2012.

Kruglanski, Arie. Lay Epistemics and Human Knowledge. New York: Plenum Press, 1989. . The Psychology of Closed-Mindedness. New York and Hove: Psychology Press, 2004.

Mannoni, Octave. "Je sais bien mais quand-même." In Clefs pour l'imaginaire. Paris: Seuil, 1969.

McCauley, Clark, and Moskalenko, Sophia. Friction: How Radicalisation Happens to Them and Us.

New York: Oxford University Press, 2011.

Merleau-Ponty, Maurice. Phénoménologie de la Perception. Paris: Gallimard, 1945.

Le Visible et l'Invisible. Paris: Gallimard, 1961.

Newey, Glen. Virtue, Reason and Toleration. Edinburgh: Edinburgh University Press, 1999.

"Political Toleration: A Reply to Jones." British Journal of Political Science 41/1 (2011):

223-227.

Nietzsche, Friedrich. Jenseits von Gut und Böse, 1886. In Nietzsche-Ausgabe, Abteilung VI, Band 2. Berlin and New York: De Gruyter, 1999.

Poellner, Peter. Nietzsche and Metaphysics. New York: Oxford University Press, 1995

Schiller, Friedrich. Über die ästhetische Erziehung des Menschen. Leipzig: Reclam, 2000.

Schutz, Alfred. “On Multiple Realities.” Philosophy and Phenomenological Research 5/4 (1945): 533-576.

Speckhard, Anne. Talking to Terrorists. McLean, VA: Advances Press, 2012. 
Steglich-Petersen, Asbjorn. “The No-Guidance Argument.” Theoria 79 (2013): 279-283.

Stroud, S., \& Tappolet, C. (eds.). Weakness of Will and Practical Irrationality. Oxford: Clarendon Press, 2003

Toscano, Alberto. Fanaticism. New York: Verso, 2016.

Velleman, David. "On the aim of belief." In The Possibility of Practical Reason. Oxford: Oxford University Press, 2000.

Veyne, Paul. Les Grecs ont-ils cru à leurs mythes? Essai sur l'imagination constituante. Paris: Seuil, 1983.

Williams, Bernard. "Ethical Consistency." in Problems of the Self, 166-186. Cambridge: Cambridge University Press, 1973.

. Ethics and the Limits of Philosophy. Cambridge, MA.: Harvard University Press, 1985.

Wittgenstein, Ludwig. Über Gewissheit. Frankfurt: Suhrkamp, 1984. 